Special issue of the International Conference on Computational and Experimental Science and Engineering (ICCESEN 2014)

\title{
Natural Radioactivity and Radiation Hazards in Coals Extracted in Amasya, Turkey
}

\author{
M.C. BOZ ${ }^{a}$, F. ÖNER ${ }^{b}$, B. MAVI ${ }^{a, *}$ \\ ${ }^{a}$ Amasya Üniversity, Faculty of Arts and Sciences, Department of Physics, Amasya, Turkey \\ ${ }^{b}$ Amasya Üniversity, Faculty of Education, Department of Computer Education and Instructional Technology, \\ Amasya, Turkey
}

\begin{abstract}
Radioactive nuclei were created at the beginning of the Universe and with a long half-life, are still present in Earth's crust. The radiations due to the radionuclides contribute to natural background radiation. This generally occurs in ground-source materials (stone, soil, rocks, etc.) in different concentrations. The levels of radiation are due to the uranium, thorium and potassium present in the material. In this study, the natural radioactivity concentrations of coals extracted in Suluova have been determined using a $\mathrm{NaI}(\mathrm{Tl}) \gamma$-ray spectrometer system. The radium equivalent activities of the samples were all below the recommended limit values $\left(370 \mathrm{~Bq} \mathrm{~kg}^{-1}\right)$. The value of external hazard indices is less than unity.
\end{abstract}

DOI: 10.12693/APhysPolA.128.B-360

PACS: 07.85.Nc, 92.20.Td

\section{Introduction}

We are constantly faced with radiation from natural resources. A large portion of the radiation we are exposed to comes from natural sources. The basis of this radiation, U-238, Th-232 and U-235 are radioactive elements that belong to the decay series. Similarly, radioactive elements that provide radiation decays are found in underground mines, such as uranium, thorium or potassium.

One of the risks to mine workers' health is exposure to the radiation in coal. Mine workers are exposed to gamma radiation released from the natural radioactive elements in geological structures [1]. The radiation doses depend on the type of mine; hours spent working in mines, production techniques and ventilation parameters [2]. In this study, the natural radioactivity concentrations of coal extracted in Suluova have been determined using a $\mathrm{NaI}(\mathrm{Tl}) \gamma$-ray spectrometer system.

\section{Materials and method}

Coal samples were collected from different layers of the coal mine $(0 \mathrm{~m}, 105 \mathrm{~m}, 115 \mathrm{~m}, 125 \mathrm{~m}, 135 \mathrm{~m}$, $150 \mathrm{~m}, 250 \mathrm{~m}$, and $330 \mathrm{~m}$ ) in Suluova. The radioactivity concentrations of ${ }^{40} \mathrm{~K},{ }^{226} \mathrm{Ra}$ and ${ }^{232} \mathrm{Th}$ were measured. The samples were crushed, sieved and dried in an oven at $90^{\circ} \mathrm{C}$ for about 20 hours to ensure that moisture was completely removed. The dry weight was taken for each sample. Then they were put in sealed polyethylene containers. The samples were submitted to gamma readings after waiting for ${ }^{222} \mathrm{Rn}$ to reach secular equilibrium with ${ }^{226} \mathrm{Ra}$ (more than one month) [3].

\footnotetext{
*corresponding author; e-mail: fbmavi32@hotmail.com
}

The natural radioactivity concentrations of coal samples were measured using the gamma spectrometer, which contains a $3^{\prime \prime} \times 3^{\prime \prime} \mathrm{NaI}(\mathrm{Tl})$ detector coupled to a digital spectrum analyzer (DSPEC LF) which was connected to the multi-channel analyser (MCA) and provided by Ortec hardware which was controlled by MAESTRO-32 software. The counting time for each sample and background was $72000 \mathrm{~s}(20 \mathrm{~h})$.

The ${ }^{226} \mathrm{Ra}$ and ${ }^{232} \mathrm{Th}$ activity concentrations were determined by the photo peaks of their daughters, ${ }^{214} \mathrm{Bi}$ $(1764 \mathrm{keV})$ and ${ }^{208} \mathrm{Tl}(2610 \mathrm{keV})$, respectively. The ${ }^{40} \mathrm{~K}$ activity concentration $A$ was determined directly from the $1460 \mathrm{keV}$ photopeak.

\section{Calculations and results}

\subsection{Activity concentration}

The activity concentrations of ${ }^{40} \mathrm{~K},{ }^{226} \mathrm{Ra}$ and ${ }^{232} \mathrm{Th}$ in $\mathrm{Bq} / \mathrm{kg}$ were computed using the following equation relation:

$$
A=N P A /(\varepsilon \cdot \gamma \cdot m),
$$

where $A$ is the counting rate of gamma rays in $\mathrm{Bq} \mathrm{kg}^{-1}$, $N P A$ is the net peak area per second. $\varepsilon$ is the detector efficiency of the specific gamma ray, $\gamma$ the absolute transition probability of gamma decay and $m$ the mass of the sample in $\mathrm{kg}[3,4]$.

The worldwide radioactivity concentrations of ${ }^{40} \mathrm{~K}$, ${ }^{226} \mathrm{Ra}\left({ }^{238} \mathrm{U}\right),{ }^{232} \mathrm{Th}$ were reported to be $140-850,17-$ 60 and 11-64 $\mathrm{Bq} \mathrm{kg}^{-1}$ respectively [5].

The activity concentrations of ${ }^{40} \mathrm{~K},{ }^{226} \mathrm{Ra}$ and ${ }^{232} \mathrm{Th}$ ranged from 96.42 to $360.73 \mathrm{~Bq} \mathrm{~kg}^{-1}, 8.40$ to $59.91 \mathrm{~Bq} \mathrm{~kg}^{-1}, 11.24$ to $51.32 \mathrm{~Bq} \mathrm{~kg}^{-1}$, respectively shown in Fig. 1.

\subsection{Radium equivalent activity}

To assess the radiological risk of the materials, it is useful to calculate an index called the radium equivalent 


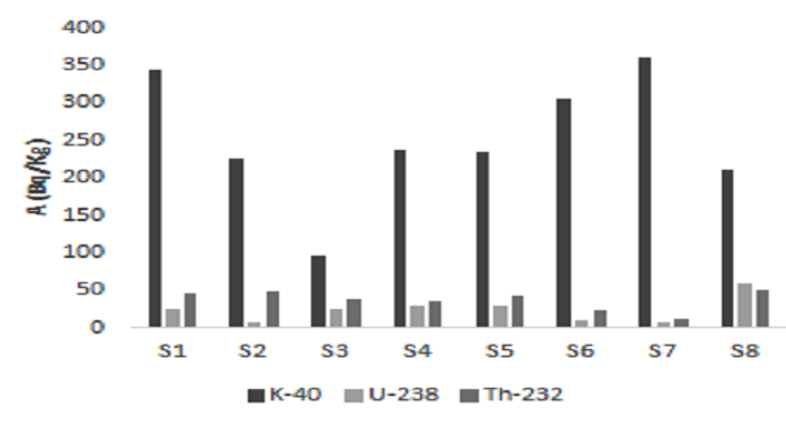

Fig. 1. ${ }^{40} \mathrm{~K},{ }^{226} \mathrm{Ra}$ and ${ }^{232} \mathrm{Th}$ activity concentrations for coals.

activity, $\mathrm{Ra}_{\mathrm{eq}}$ in $\mathrm{Bq} \mathrm{kg}^{-1}$. It is a common index used to compare the activity concentrations of samples containing ${ }^{40} \mathrm{~K},{ }^{226} \mathrm{Ra}$ and ${ }^{232} \mathrm{Th}$. It is a weighted sum of activities of the based on the assumption that $370 \mathrm{~Bq} \mathrm{~kg}^{-1}$ of ${ }^{226} \mathrm{Ra}, 259 \mathrm{~Bq} \mathrm{~kg}^{-1}$ of ${ }^{232} \mathrm{Th}$ or $4810 \mathrm{~Bq} \mathrm{~kg}^{-1}$ of ${ }^{40} \mathrm{~K}$ produces the same gamma-ray dose rate $[6,7]$.

$\mathrm{Ra}_{\mathrm{eq}}$ is calculated using the following equation, as described by UNSCEAR [8],

$$
\mathrm{Ra}_{\mathrm{eq}}=A_{\mathrm{Ra}}+1.43 A_{\mathrm{Th}}+0.077 A_{\mathrm{K}},
$$

where $A_{\mathrm{Ra}}, A_{\mathrm{Th}}$ and $A_{\mathrm{K}}$ are the activity concentrations of ${ }^{226} \mathrm{Ra},{ }^{232} \mathrm{Th}$ and ${ }^{40} \mathrm{~K}$, respectively, in $\mathrm{Bq} \mathrm{kg}^{-1}$. The results range from 49.96 to $148.11 \mathrm{~Bq} \mathrm{~kg}^{-1}$ as shown in Fig. 2. $\mathrm{Ra}_{\mathrm{eq}}$ values of lower than the recommended maximum limit value of $370 \mathrm{~Bq} \mathrm{~kg}^{-1}$ [9].

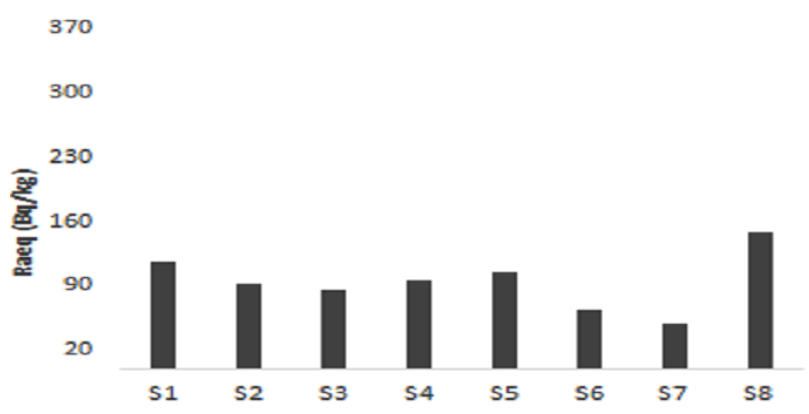

Fig. 2. Radium equivalent activity for coals.

\subsection{Absorbed dose rate}

To evaluate the external exposure from naturally occurring radionuclides, the air absorbed dose rate $D$ due to terrestrial gamma rays at $1 \mathrm{~m}$ above the ground was calculated from ${ }^{226} \mathrm{Ra},{ }^{232} \mathrm{Th}$ and ${ }^{40} \mathrm{~K}$ concentration values using the formula [5]:

$$
D[\mathrm{nGy} / \mathrm{h}]=0.462 A_{\mathrm{Ra}}+0.604 A_{\mathrm{Th}}+0.0417 A_{\mathrm{K}} .
$$

It can be seen that the absorbed dose rate ranged from 25.82 to $67.50 \mathrm{nGy} \mathrm{h}^{-1}$ as shown in Fig. 3. This is within the world range $18-93 \mathrm{nGy} \mathrm{h}^{-1}[5]$. The absorbed dose values are within the world range value.

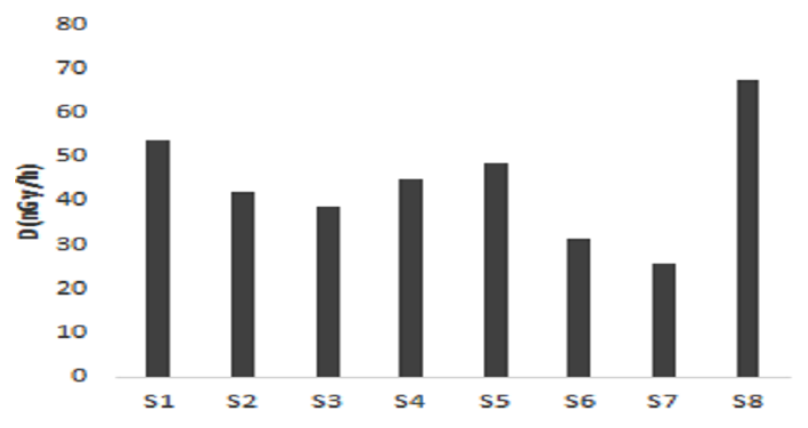

Fig. 3. Absorbed dose rate for coals.

\subsection{External radiation hazard index}

The external radiation hazard index $H_{\text {ex }}$ due to the emitted gamma-rays of the samples is calculated from the following equation [7]:

$$
H_{\mathrm{ex}}=C_{\mathrm{Ra}} / 370+C_{\mathrm{Th}} / 259+C_{\mathrm{K}} / 4810 \leq 1 .
$$

The value of $H_{\mathrm{ex}}$ must be less than unity. The results range from 0.141 to 0.404 as shown in Fig. 4. It is clear that all measured results are much lower than upper limit of the unity.

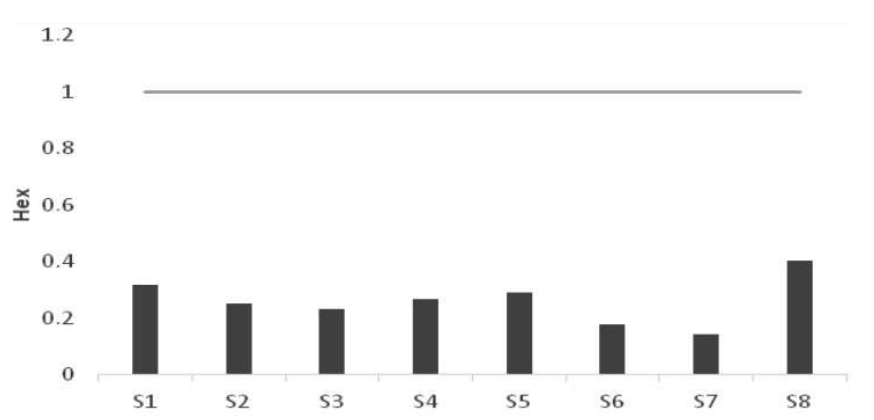

Fig. 4. Hazard index for coals and comparison with the limit value of the unity.

\section{Conclusions}

From these results, it can be inferred that the general distribution of activity concentrations are tolerable. Furthermore, the calculated radiological effect is lower than the recommended limit value. The radium equivalent activities obtained for the samples in this study were all below the recommended limit values $\left(370 \mathrm{~Bq} \mathrm{~kg}^{-1}\right)$. The value of external hazard indices is less than unity.

\section{Acknowledgments}

The authors wish to thank Scientific Research Projects Unit of Amasya University (FMB-BAP-064) and the staff of the Amasya (Suluova) coal mines. 


\section{References}

[1] A. Fişne, G. Ökten, N. Çelebi, in: Türkiye 14 Kömür Kongresi Bildiriler, Kitabı 2004, (in Turkish).

[2] E. Küçüktaş, Ph.D Thesis, Ege Üniversitesi, Nükleer Enerji Enstitüsü, İzmir 1996, (in Turkish).

[3] B. Mavi, I. Akkurt, Rad. Phys. Chem. 79, 933 (2010).

[4] I. Akkurt, B. Mavi, H. Akyıldırım, K. Günoğlu, Int. J. Phys. Sci. 4, 403 (2009).

[5] Exposure from natural sources of radiation. United Nations Scientific Committee on the Effects of Atomic Radiation UNSCEAR, 2000 Report to the General Assembly, with annexes.

[6] E.M. Krisiuk, S.I. Tarasov, V.P. Shamov, N.I. Shlak, E.P. Lisachenko, L.G. Gomslsky, A study of radioactivity in building materials, Research Institute of Radiation Hygiene, Leningrad 1971.
[7] J. Beretka, P.J. Mathew, Health Phys. 48, 87 (1985).

[8] Ionizing Radiation: Sources and Biological Effects, United Nations Scientific Committee on the Effects of Atomic Radiation UNSCEAR, 1982 Report to the General Assembly, with annexes.

[9] Exposure to radiation from the natural radioactivity in building materials, Organization for Economic Cooperation and Development OECD, Nuclear Energy Agency Report 1979 by a group of experts of the OECD Nuclear Energy Agency. 